\title{
THE VICTIM AND PROSECUTORIAL DISCRETION: THE FEDERAL VICTIM AND WITNESS PROTECTION ACT OF 1982
}

\author{
Abraham S. Goldstein*
}

I

INTRODUCTION

The American public prosecutor exercises a remarkable degree of discretion. In recent years, that discretion has been exposed to public view by a host of empirical studies and, more significantly, by the Supreme Court's legitimation of plea bargaining. One result of these developments has been a gradual change in the relationship between prosecutor and judge. For example, prosecutorial discretion was once regarded by the courts as virtually inviolate. A distinction is now drawn in most jurisdictions between the original charge and the dismissal or reduction of charges after the judicial process has begun. In those jurisdictions, the prosecutor must obtain judicial approval before he may dismiss prosecutions or conclude plea bargains in felony cases. Moreover, influential appellate courts have said a prosecutor may not dismiss cases without a rational basis for doing so. And he may not enter into plea bargains which are contrary to the "sound administration of justice." Even the original charging decision has occasionally been subjected to judicial scrutiny in cases involving denial of equal protection by "selective prosecution." 1

As courts have tried to define a limited judicial role in reviewing official action, prosecutors have responded with their own initiatives. Among them has been the suggestion that there should be more administrative rules and

\section{Copyright $(1984$ by Law and Contemporary Problems}

* Sterling Professor of Law, Yale Law School. The research and writing of this article was supported by an award to Yale Law School from The Daniel and Florence Guggenheim Foundation.

1. For a fuller discussion, see generally A. Goldstein, The Passive Judiciary: Prosecutorial Discretion and the Guilty Plea (1981); F. Miller, Prosecution: The Decision to Charge a Suspect with a Crime (1970); D. Newman, Conviction: The Determination of Guilt or Innocence without Trial (1966); M. Heumann, Plea Bargaining: The Experiences of Prosecutors, Judges, and Defense Atrorneys (1978). The principal cases are: On plea bargains, see Brady v. United States, 397 U.S. 742 (1970); Bordenkircher v. Hayes, 434 U.S. 357 (1978). On selective prosecution, see Oyler v. Boles, 368 U.S. 448, 456 (1962); United States v. Falk, 479 F.2d 616 (7th Cir. 1973). On judicial review of dismissals and guilty pleas, see United States v. Ammidown, 497 F.2d 615 (D.C. Cir. 1973); United States v. Cowan, 524 F.2d 504 (5th Cir. 1975), cert. denied, 425 U.S. 471 (1976). 
more internal guidelines ${ }^{2}$ - to give content to the broad authority usually conferred upon prosecutors. By urging the adoption of what they describe as self-enforcing "rules" and "guidelines" for the exercise of their discretion, they have tried to reassure the courts and the public that they are applying rational standards-while at the same time hoping to check or limit the movement towards judicial review of their decisions.

As a new relationship between prosecutor and judge has begun to take shape, a new factor, a victims' movement, has emerged, which is likely to have a significant effect on the nature of the relationship. The members of this movement allege that victims have become alienated from the criminal justice system, and that the result has been a notable decline in crime reports to the police, in citizen cooperation with the prosecutor, and in public confidence in the administration of justice. This alienation is said to trace not only to the commonly cited causes-ineffective detection and fear of intimidation and reprisal-but also to the neglect of victims by police, prosecutors, and judges. $^{3}$

In an effort to respond to this sense of alienation, prosecutors and judges have experimented with a wide variety of remedial measures, some of which have subsequently been mandated by state legislatures. Among these measures are providing social services to the victim-as-witness, offering the victim economic incentives by way of restitution or compensation for the injury done to him, protecting him from intimidation or retaliation, and taking his views into account at critical stages of the criminal justice process. Collectively, these remedies pursue the theme of fairness to the victim while seeking to encourage his cooperation with law enforcement authorities. By taking account of the victim's interest in financial as well as emotional satisfaction, they are expected to produce more deterrence of crime as well as a system which is more responsive to the public.

In this article, I shall consider one of these, remedies-increasing the victim's participation at critical stages of the criminal justice system-as developed in the federal Victim and Witness Protection Act of 1982.4 After sketching some background on the disparate nature of victims, I shall consider whether the statute's provisions for a victim impact statement and for "consultation with the victim"'5 have adequately defined the role to be played by the victim, whether the relation of the victim to judicial review of prosecutorial authority has been taken into account, and what effect the new

2. On prosecutorial guidelines and standards, see Abrams, Internal Policy: Guiding the Exercise of Prosecutorial Discretion, 19 U.C.L.A. L. Rev. 1 (1971); Standards Relating to The Prosecution Function and the Defense Function $\$ 2.5$ (1971); K. Davis, Discretionary Justice: A Preliminary Inquiry 224-25 (1969); U.S. Dep't of Justice, Principles of Fed. Prosecution (July, 1980), reprinted in 27 Crim. L. ReP. 3277 (BNA) (Aug. 6, 1980).

3. The victim's movement and its effects on criminal justice reform are discussed in Goldstein, Defining the Role of the Victim in Criminal Prosecution, 52 Miss. L.J. 515 (1982); see also President's TASK Force on Victims of Crime, Final Report (Dec. 1982).

4. Public L. No. 97-291, 96 Stat. 1248 (codified at 18 U.S.C. $\$ \S 1501$ note, 1503, 1505, 1510 , 1512 note, 1512-1515, 3146 note, 3579, 3580, (1982)); FED. R. CRIM. P. 32(c)(2).

5. 18 U.S.C. $\$ 1512$ note (1982); FED. R. CRIM. P. 32(c)(2). 
statute may have on the operation of the criminal justice system. My objective at this early stage is not to attempt definitive answers to these questions but instead to provide a preliminary assessment, as a basis for further consideration of the important issues of law and policy presented by the Act.

\section{II}

\section{The Differential Nature of Victim Influence}

A discussion of the relation between the victim and prosecutorial discretion is complicated by the ambiguity of each of the critical words and concepts. At least in the United States, the word "prosecutor" describes a decentralized set of officials, each of whom enjoys an authority in his jurisdiction comparable to that of the Attorney General of the United States in the federal system. The word "discretion" describes an authority tailored to the infinite variety of circumstances which arise as particular facts interact with the general language of criminal statutes and enforcement policies. And the word "victim" refers to a wide variety of crimes and fact situations-with the victim more often identifiable in state criminal law than in federal law.

The relation of the victim to each crime category tends to define his relation to the prosecutor and the manner in which discretion is exercised. ${ }^{6}$ In traditional crimes of violence and property the victim's complaint tends to initiate and sustain the case. If he chooses not to complain, or if he abandons his complaint by not cooperating any further, the prosecutor generally treats the decision as the victim's to make, almost as if it is a "private" decision and the prosecutor is merely a surrogate for the victim. Much the same is true of the prosecutor's relation to regulatory agencies. Although individuals are often victimized by regulatory crimes, such as health and safety violations, environmental offenses, and frauds, the nature of these offenses is such that the injury to any particular individual may be intangible or small. The victim's interests, therefore, are represented by a public agency and in most instances the prosecutor will not file a criminal charge unless urged to do so by the agency.

In the case of "victimless" crimes, such as gambling and narcotics, which are said to make society the victim, the groups interested in enforcement are so diverse that the prosecutor may properly regard himself as more representative than any group claiming to represent the public interest. As a result, it

6. See generally Hall, The Role of the Victim in the Prosecution and Disposition of a Criminal Case, 28 Vand. L. Rev. 931 (1975); Vera Institute of Justice, Felony Arrests: Their Prosecution and Disposition in New York City's Courts 135-40 (1977); R. Davis, V. Russell \& S. Kunreuther, The Role of the Complaining Witness in an Urban Criminal Court (1980); Davis, Victim/Witness Noncooperation: A Second Look at a Persistent Phenomenon, 11 J. Crim. Just. 287 (1983); Hindelong \& Gottredson, The Victim's Decision Not to Invoke the Criminal Justice Process, in Criminal Justice and The VICTIM 75-77 (W. McDonald ed. 1976); McGuir \& Edelhertz, Consumer Abuse of Older Americans: Victimization and Remedial Action in Two Metropolitan Areas, in WhIte Collar Crime: Theory and Research 266, 266-90 (G. Geis \& E. Stotland eds. 1980); Walsh \& Schram, Accuser or Accused in White CollaR Crime: Theory and Research, supra at 32, 42-45. For illustrative statistics, see Law ENFORCEMENT Assistance Admin., U.S. Dep'T of Justice, Criminal Victimization in the United States 1973,1 158 (1976). See also Rabin, Agency Criminal Referrals in the Federal System: An Empirical Study of Prosecutorial Discretion, 24 Stan. L. REv. 1036 (1972). 
is often said that it is his initiative (and that of the police) which determines almost entirely whether there will be a prosecution. Yet that characterization is perhaps an over-simplification. There are sometimes constituencies, such as businesses and neighborhood residents adversely affected by streetwalkers, which regard themselves as "victimized" by the consensual activity. In practice, these constituencies may become the "victims" who complain to the police and to whom prosecutors may defer in deciding whether or not to prosecute.

In sum, where there are no identifiable victims, the prosecutor's initiative is critical. Where there are victims, or agencies representing them, he generally acts on matters which are brought to him. If these matters pass the test of evidentiary and legal sufficiency (and a great many do not), they will be prosecuted, provided they satisfy several other criteria: Are the crimes serious enough? Are prosecutorial resources sufficient to the task? Do the prosecutor (and his community) agree with the public policy reflected in the statute? This last factor raises the risk of prosecutorial "nullification," which has a counterpart in what might be called victim "nullification." The latter occurs in cases which are not reported to the authorities, or which are later abandoned because the victims prefer to resort to self-help or because they wish to avoid the problems associated with adverse publicity. For example, if victimized stores elect not to prosecute shoplifters, if banks prefer not to prosecute embezzlers, if victimized women elect not to press rape charges, if businesses generally prefer to discharge rather than prosecute employees who steal from them, police and prosecutor are not likely to press for prosecution.

It appears, then, that the prosecutor's decision is usually reactive. Although he does not explicitly delegate his authority, he tends to confirm the victim's decision either to prosecute or not to prosecute, if that decision is supported by the police. I do not mean to suggest that the prosecutor never tries to persuade a victim to stay the course. After all, the unwilling or reluctant victim can be compelled to testify. But such compulsion is rare because it is assumed that an unwilling witness will not be persuasive to judge or jury. Yet that assumption begs a series of questions. Should it be assumed, for example, that the victim who expresses a desire not to testify will do so untruthfully or unpersuasively if he is summoned to the witness stand? Since most cases are decided by guilty pleas, is it perhaps premature to refuse to charge because a victim announces at an early stage that he will not testify if, and when, a contested trial takes place? Are there classes of cases in which prosecutors should try harder to gain the victim's cooperation and perhaps compel him (or her) to testify? ${ }^{7}$

7. See, e.g., L. Lerman, Prosecution of Spouse Abuse: Innovations in Criminal Justice Response (1981). On August 8, 1983, the New York Times reported an experiment by the municipal prosecutor's office in Anchorage, Alaska, in which battered women were compelled to testify against their assailants even if they wished to drop the charges. One woman who refused to testify was jailed briefly for contempt of court. Id. 
Up to this point, I have referred principally to the initial decision to prosecute or not to prosecute. Victim complaints are also directed at prosecutorial neglect or domination once a victim has cooperated and the prosecution has begun. It is said that cooperating victims too often are not consulted or even informed of decisions on pretrial release, dismissal, charge reduction, guilty pleas, continuances, and sentences. And if the victim does learn what is happening and wishes to express his views to the prosecutor or judge, he is regarded as a "mere witness" who has no standing in the matter. The prosecutor alone is said to represent the public interest.

Though the victim may begin with the assumption that it is the wrong against him that is to be requited by the criminal law - that the prosecutor is his surrogate, proceeding in his place and on his behalf-he is too often persuaded by the 'system' that the criminal prosecution is not really 'his' business at all. ${ }^{8}$

Of course, reports of prosecutorial insensitivity are less likely to be true now than they were before the victims' movement appeared. Nevertheless, such reports persisted long enough to set the stage for enactment of a new federal statute in the summer of 1982 .

\section{III}

\section{The Victim and Witness Protection Act}

The federal Victim and Witness Protection Act of $1982^{9}$ begins with a series of "findings and purposes." It describes the "cooperation of victims and witnesses" as essential to a functioning criminal justice system and finds that victims and witnesses are "either ignored . . or simply used as tools to identify and punish offenders." The system is said to be "unresponsive to the[ir] real needs." Victims and witnesses are not sufficiently protected from intimidation; they are not provided with counsel; they are not routinely notified of the dates when critical decisions are to be made on pretrial release, dismissal or reduction of charges, plea bargains, or continuances. They are provided with inadequate services at the courthouse and the return of their stolen property is not facilitated. ${ }^{10}$

Congress declared its purpose to "enhance and protect the necessary role of crime victims" 11 and provided a series of remedies-among them several relevant to the exercise of prosecutorial and judicial discretion. One section of the Act requires that a victim impact statement be included in the presentence report prepared by the probation officer for the sentencing judge. ${ }^{12}$ A second section deals in some detail with restitution. ${ }^{13}$ And a third directs the Attorney General to issue guidelines which will assure the fair treatment of victims and witnesses by the United States Department of Justice,

8. Goldstein, supra note 3 , at 520 .

9. 18 U.S.C. $\S 1512$ note (1982).

10. These "Findings and Purposes" comprised section 2 of the Act, supra note 4, and are now found in 18 U.S.C. $\$ 1512$ note (1982).

11. Id. $\$ 2(\mathrm{~b})(\mathrm{l})$.

12. Fen. R. CRIM. P. 32(c)(1),(2).

13. 18 U.S.C. $\$ 3580(\mathrm{a})-3580$ (b) (1982). 
including "consultation with the victim" at specified stages of the criminal process. ${ }^{14}$ The guidelines subsequently issued by the Attorney General enlarge significantly on the Act's coverage. ${ }^{15}$ They "incorporate victim and witness assistance concepts beyond those set out in the . . . [Act], in particular, pertinent recommendations of the President's Task Force on Victims of Crime." 16 In the pages that follow, I shall discuss these remedies and particularly the part to be played in them by the victim.

\section{A. Consultation with the Victim}

Section 6(a)(5) of the Act directs the Attorney General to develop guidelines for the Department of Justice on "consultation with the victim." The section reads:

The victim of a serious crime, or in the case of a minor child or a homicide, the family of the victim, should be consulted by the attorney for the Government in order to obtain the views of the victim or family about the disposition of any Federal criminal case brought as a result of such crime, including the views of the victim or family about-
(A) dismissal;
(B) release of the accused pending judicial proceedings;
(C) plea negotiations; and
(D) pretrial diversion program. ${ }^{17}$

14. Section 4(a) of the Act, 18 U.S.C. $\$ \$ 1512-1515$ (1982), provides new protections from intimidation for victims and witnesses. There are two other short provisions: Section 7, 18 U.S.C. $\S 3579$ note (1982), directs the Attorney General to report to Congress on laws that might be necessary to prevent a federal felon from profiting from the sale of his story, "until any victim of the offense receives restitution"; Section 8 makes some changes in the language of 18 U.S.C. $\$ 3146(a)$.

15. Attorney General's Guidelines for Victim and Witness Assistance, July 9, 1983, reprinted in 33 Crim. L. ReP. 3329 (Aug. 3, 1983). On August 23, 1983, the Attorney General issued a Memorandum on implementation of the restitution provisions of the Act.

16. Id. $\S \mathrm{I}(\mathrm{A})$ para. 3.

17. 18 U.S.C. $\$ 1512$ note (1982). The Act does not define "serious crime." The AtTorney General's Guidelines, supra note $15, \S \mathrm{I}(\mathrm{C})(3)$, define the phrase as "a criminal offense that involves personal violence, attempted or threatened personal violence or significant property loss." The text, in substantial part, of section 6,18 U.S.C. $\$ 1512$ note, follows:

(a) . . . the Attorney General shall develop and implement guidelines for the Department of Justice consistent with the purposes of this Act. In preparing the guidelines the Attorney General shall consider the following objectives:

(1) SERVICES TO VICTIMS OF CRIME.-Law enforcement personnel should ensure that victims routinely receive emergency social and medical services as soon as possible and are given information on the following-

(A) availability of crime victim compensation (where applicable);

(B) community-based victim treatment programs;

(C) the role of the victim in the criminal justice process, including what they can expect from the system as well as what the system expects from them; and

(D) stages in the criminal justice process of significance to a crime victim, and the manner in which information about such stages can be obtained.

(2) NOTIFICATION OF AVAILABILITY OF PROTECTION . .

(3) SCHEDULING CHANGES.-All victims and witnesses who have been scheduled to attend criminal justice proceedings should either be notified as soon as possible of any scheduling changes which will affect their appearances or have available a system for alerting witnesses promptly by telephone or otherwise.

(4) PROMPT NOTIFICATION TO VICTIMS OF MAJOR SERIOUS CRIMES._Victims, witnesses, relatives of those victims and witnesses who are minors, and relatives of homicide victims should, if such persons provide the appropriate official with a current address and 
The text of the Act is plainly meant both to enlarge the criteria for decisions made by the prosecutor and judge and to benefit the victim. The Act assures the victim of a "serious crime" that his views "about the disposition of any Federal criminal case brought as a result of such crime" will be sought by the prosecutor, at least at the four stages designated. The italicized words are particularly significant because they distinguish between the conduct of the offender and the prosecution brought as a result of such conduct. The former is made the occasion for consulting the victim about the "criminal case brought as a result of such crime." The statutory distinction between "serious crime" and "any Federal criminal case" would seem, therefore, either to identify the former with the real offense and the latter with the legal offense selected for prosecution, or to preserve the prosecutor's discretion to charge the serious crime at the outset while retaining the victim's right to be consulted at later stages on less serious charges "brought as a result of" the serious crime.

The guidelines enlarge upon the Act in several important respects. For example, they impose obligations on the prosecutor to consult victims of serious crime at nine stages, rather than the four stages specified in the statute. The five additional stages are:

(2) The decision not to seek an indictment or otherwise commence a prosecution; . .

(4) Any continuances of a judicial proceeding; . . .

(7) The proposed proceeding against the accused as a juvenile defendant;

telephone number, receive prompt advance notification, if possible, of judicial proceedings relating to their case, including-

(A) the arrest of an accused;

(B) the initial appearance of an accused before a judicial officer;

(C) the release of the accused pending judicial proceedings; and

(D) proceedings in the prosecution of the accused (including entry of a plea of guilty, trial, sentencing, and, where a term of imprisonment is imposed, the release of the accused from such imprisonment).

(5) CONSULTATION WITH VICTIM..... . [quoted in text above];

(6) SEPARATE WAITING AREA.-Victims and other prosecution witnesses should be provided prior to court appearance a waiting area that is separate from all other witnesses.

(7) PROPERTY RETURN.-Law enforcement agencies and prosecutor should promptly return victim's property held for evidentiary purposes unless there is a compelling law enforcement reason for retaining it.

(8) NOTIFICATION TO EMPLOYER.-A victim or witness who so requests should be assisted by law enforcement agencies and attorneys for the Government in informing employers that the need for victim and witness cooperation in the prosecution of the case may necessitate absence of that victim or witness from work. A victim or witness who, as a direct result of a crime or of cooperation with law enforcement agencies or attorneys for the Government, is subjected to serious financial strain, should be assisted by such agencies and attorneys in explaining to creditors the reason for such serious financial strain.

(9) TRAINING BY FEDERAL LAW ENFORCEMENT TRAINING FACILITIES.-Victim assistance education and training should be offered to persons taking courses at Federal law enforcement training facilities and attorneys for the Government so that victims may be promptly, properly, and completely assisted.

(10) GENERAL VICTIM ASSISTANCE.-The guidelines should also ensure that any other important assistance to victims and witnesses, such as the adoption of transportation, parking, and translator services for victims in court be provided.

(b) Nothing in this title shall be construed as creating a cause of action against the United States.... 
(8) Restitution ... ;

(9) Presentation to the court of the victim's views regarding sentencing. ${ }^{18}$

The victim is to be "provide[d] with explanations" for the decisions at all nine stages. ${ }^{19}$ His views are to be sought regarding "any sentencing recommendation to be made by the prosecutor" as part of a plea negotiation..$^{20}$ And he is to be informed of "the opportunity to address the court at the time of sentencing." 21

Both the statute and the guidelines seem to filter the victim's views through the prosecutor. The victim is given no explicit right to present his views to the court directly or to present evidence, except perhaps at sentencing. It is not at all clear, however, what uses are to be made of the victim's views by either the prosecutor or the court. For example, must the prosecutor report to the court the views he has obtained from the victim? If prosecutor and victim disagree, may the victim bring his views to the attention of the court? Are there circumstances when the court may or must consult the victim directly? May or must the victim be represented by counsel and in what fashion? May the victim call witnesses or suggest to the court that it call witnesses on his behalf? On what issues? Does the Act contemplate that the guidelines are to be self-policed by the Attorney General and his subordinate prosecutors? Or is there a role for victim and court to play in compelling compliance with the Act and the guidelines? Will the court compel a prosecutor to consult the victim? To conduct a "meaningful" consultation? To prosecute?

Each of the occasions for "consultation with the victim"- the four set out in the Act and the five added by the guidelines-present different problems in defining the role to be accorded the victim's views. Under existing federal law, some of the decisions to be made on those occasions are left exclusively to the prosecutor while others are subject to some sort of judicial review. For example, no judicial role is now involved in the prosecutor's decision not to seek an indictment or otherwise commence a prosecution. ${ }^{22}$ The victim's views on initiating prosecution, therefore, are presumably meant for the prosecutor alone and need not be shared with the court. On the other hand, dismissals and plea bargains must be approved by the court, even when recommended by the prosecution and agreed to by the defendant. ${ }^{23}$ Since the court may take into account the "sound administration of justice" in deciding such matters, the prosecutor may be obligated to consult the victim and to transmit the victim's views to the court, especially if they differ from the prosecution's. ${ }^{24}$ If the prosecutor does not do so, the court may decide

18. Attorney General's Guidelines, supta note 15 , § II(C).

19. Id.

20. Id. $\S \mathrm{II}(\mathrm{C})(5)$.

21. Id. $\S \mathrm{II}(\mathrm{B})(8)$.

22. See, e.g., United States v. Cowan, 524 F.2d 504, 513 (5th Cir. 1975), cert. denied, 425 U.S. 971 (1976).

23. See Fed. R. CRIM. P. 11, 48(a).

24. Cowan, supra note 22, at 512-15; see also Rinaldi v. United States, 434 U.S. 22, 29-30 n.15 (1977); United States v. Ammidown, 497 F.2d 615, 618-19, $621-23$ (D.C. Cir. 1973); A. Goldstein, supra note 1 , at $12-24,47-51$. 
that its discretion encompasses hearing the victim's views and even permitting him to appear at the hearing on the dismissal or guilty plea. In short, although the statute does not explicitly confer upon the victim a right to a hearing at such stages, the trial judge, at the request of the victim, probably may compel the prosecutor to do his duty under the statute.

A similar analysis can be applied to the victim's right to be heard on pretrial release and on pretrial diversion. The former unmistakably calls for a judicial decision; the latter, according to some views, is a prosecutorial decision. ${ }^{25}$ The prosecutor would seem to be obligated by the Act not only to consider the victim's views on pretrial release but also to transmit them to the court-particularly when he and the victim disagree-so that the judge may make his own assessment, even if this includes inviting the victim to express his views directly. On the other hand, where the victim's views on pretrial diversion are addressed to the prosecutor's discretion alone, the court's role may be limited to requiring the prosecutor to hear those views.

Although the Act and the guidelines contemplate that the victim's views will be considered by the prosecutor in exercising his discretion, it does not follow that the prosecutor must accept those views. For example, if the victim of a bank embezzlement urges prosecution, the prosecutor must take that view into account. But if he concludes that there should be no prosecution at all because the defendant is a first offender and there are strong mitigating factors, or that prosecution should be accompanied by pretrial diversion, he need not accept the victim's views and abandon his own. The reference in the guidelines to "explanations" which must be given by prosecutors to victims at each of several stages supports such an interpretation. These explanations presumably become necessary only when the prosecutor disagrees with the victim at any of the nine specified stages.

The conclusion that the prosecutor need not accept the victim's views is perhaps less clear at sentencing and restitution than at the other consultative stages. Under the guidelines, it is only at sentencing ${ }^{26}$ and with respect to restitution ${ }^{27}$ that the prosecutor is told he should advocate the interests of victims. These provisions not only suggest that the prosecutor is obligated to present the victim's as well as his own views on sentencing and restitution to the judge; they also raise a more fundamental question: Are the provisions meant to impose an obligation on the prosecutor to subordinate his views on sentencing to those of the victim? And is he to be a victim-surrogate when restitution and sentencing play a role in plea negotiations?

25. See generally President's Commission on Law Enforcement and Administration of Justice, The Challenge of Crime in a Free Society 133-34 (1967). Compare Shade v. Pennsylvania Dep't of Transp., 394 F. Supp. 1237, 1242 (M.D. Pa. 1975) (approving pretrial diversion at prosecutor's discretion) with State v. Leonardis, 375 A.2d 607 (N.J. 1977) (court may review diversion decision).

26. Prosecutors are to do so "[clonsistent with available resources and their other responsibilities." AtTorney General's Guidelines, supra note $15, \S$ III.

27. The obligation is imposed "unless such advocacy would unduly prolong or complicate the sentencing proceeding." ATtorney General's Guidelines, supra note 15, § IV. 


\section{B. Sentencing, Restitution, and the Victim Impact Statement}

Under the Act, a victim impact statement must now be prepared by the probation officer as part of the presentence report provided to the sentencing judge. ${ }^{28}$ Two classes of information bearing on the victim must be included in that statement:

(c) information concerning any harm, including financial, social, psychological, and physical harm, done to or loss suffered by any victim of the offense; and

(d) any other information that may aid the court in sentencing, including the restitution needs of any victim of the offense."29

The report which provides a basis for for the court's sentencing decision, makes harm to the victim a factor to be weighed explicitly, along with the rehabilitative and deterrent interests which have come to dominate the sentencing process. Moreover, the restitution remedy is placed on a firm foundation. Where prior federal law had authorized restitution only as a condition of probation, the new Act provides that the court "may order, in addition to or in lieu of any other penalty authorized by law, that the defendant make restitution to any victim of the offense." 30 The presentence report must now furnish details relevant to the judge's decision on restitution"1 which must be "as fair as possible to the victim," but may not "unduly complicate or prolong the sentencing process." 32 If there is a dispute as to the amount, the matter is to be decided "by the preponderance of the evidence." The prosecutor carries "the burden of demonstrating the amount of the loss sustained by the victim as a result of the offense." The defendant carries the burden of showing a lack of financial resources. ${ }^{33}$

Overall, the scales are tilted towards restitution not only by the Act's history but also by its requirement that a judge who does not order restitution must "state on the record the reasons" for not doing so. ${ }^{34}$ Taken together, these provisions seem to make the victim a beneficiary, in his own right, of the

28. See Fed. R. Crim. P. 32(C)(1),(2).

29. Victim and Witness Protection Act $\S 3$, FED. R. CRIM. P. 32(C)(2). This provision should be read in conjunction with section 5 , the restitution section, 18 U.S.C. $\S 3580(a), 3580$ (b), which contemplates the gathering of additional information about the victim's losses and injuries. Compare the Indiana provisions for solicitation of victim's statements:

(a) [The probation officer's] presentence investigation . . . must include ...

(3) Any written statements submitted to the probation officer by a victim.

(b) If there are no written statements submitted to the probation officer, he shall certify to the court:

(1) That he has attempted to contact the victim; and

(2) That, if he has contacted the victim, he has offered to accept the written statements of the victim, or to reduce his oral statements to writing, concerning the sentence, including the acceptance of any recommendation.

Ind. Code ANn. § 35-50-1A-10 (Burns 1979).

30. Victim and Witness Protection Act $\$ 5(\mathrm{a}), 18$ U.S.C. $\$ 3579(\mathrm{a})(1)$ (1982). Under the Act, restitution may be ordered only for property losses and, in cases of bodily injury, for medical and related expenses and for loss of income. An award of restitution does not bar a civil action by the victim; it is a set-off against a recovery. 18 U.S.C. $\$ 3579(\mathrm{e})(2)(1982)$.

31. 18 U.S.C. $\$ 3580$ (a), (b) (1982).

32. 18 U.S.C. $\$ 3579$ (d) (1982).

33. 18 U.S.C. $\$ 3580$ (d) (1982).

34. 18 U.S.C. $\$ 3579$ (a)(2) (1982). 
criminal proceeding. The victim's injuries must be assessed and restitution is to be awarded to him if at all possible. The court's order of restitution may be enforced either by the victim named in the order or by the United States in the same way as a judgment in a civil action. ${ }^{35}$ And the criminal conviction "shall estop the defendant from denying the essential allegations of the offense" in subsequent civil proceedings brought by the victim. ${ }^{36}$

Despite the clear congressional purpose to benefit the victim and to provide restitution, the Act has left many issues unresolved. A dramatic illustration arises from the fact that the likelihood of restitution, and the amount to be awarded, may affect whether the victim will report the crime against him and will cooperate in its prosecution. If the criminal charge-which becomes the basis for the award-is not framed to take account of the victim's restitutionary interest, it may not provide an adequate legal basis for restitution or a sufficient incentive for reporting and cooperation. For example, if the charge is reduced (in degree or number) in the course of plea bargaining, the victim's interests may be neglected unless special measures are taken to include restitution for uncharged or dismissed offenses as part of a plea agreement. Does it follow, therefore, that the victim's restitutionary interest in the charge gives him the right to participate in the hearing on the dismissal or the guilty plea, so that he may argue for a plea to offenses which offer the best prospect for restitution? ${ }^{37}$

Other illustrations come readily to mind. What if the probation officer does not supply the restitution information required by statute? Is it only the judge, for whom the probation officer's report is prepared, who can complain? What about the prosecutor? Or the defendant who may be concerned not only about the amount owed but also about his restitutionary liability being caught up in the coercive atmosphere of plea bargaining? Is the victim himself entitled to be heard and to insist that material be included in the presentence report-as bearing on the sentence and on the restitution decision? If the victim cannot participate as a party at the sentencing stage, can he require the prosecutor to present and protect his restitutionary interests?

The Act says nothing explicit on these matters. And the law of sentencing offers little guidance. That body of law is relatively informal-not only for sentencing but also for the restitution sometimes ordered as a condition of probation. There are relatively few hearing "rights," with courts often relying on advices, letters, and affidavits. Even defendants have at best limited rights to present witnesses, to see presentence reports or to confront witnesses

35. 18 U.S.C. $\& 3579$ (h) (1982).

36. 18 U.S.C. $\$ 3580$ (e) (1982) (The collateral estoppel applies to "any subsequent Federal civil proceeding or State civil proceeding, to the extent consistent with State law, brought by the victim").

37. See Goldstein, supra note 3, at 536-42, for a discussion of the "real offense," the offense-ofconviction and the plea agreements as the appropriate basis for restitution. Issues of procedure associated with the restitution award are discussed id. at 544-46; see also United States v. McLaughlin, 512 F. Supp. 907, 909-10 (D. Md. 1981); Note, Restitution in the Criminal Process: Procedures for Fixing the Offender's Liability, 93 YALE L.J. 503 (1984). 
referred to in reports, or to exercise rights of "allocution."38

Nothing in the Act suggests that the victim's procedural rights at sentencing are meant to be greater than the defendant's or that they need be as great. The statute's provision on the "victim impact statement" says nothing about a role for the victim except through the probation officer. ${ }^{39}$ And its section on "consultation with the victim" does not specify sentencing among the stages at which victims of serious crimes must be consulted by the prosecutor. ${ }^{40}$ The Attorney General's guidelines do have some things to say on the matter but they are not decisive. On the one hand, they seem to suggest that the victim's views are to be presented only by the prosecutor. For example, they direct the prosecutor to consult victims regarding (1) "the proposed terms of any negotiated plea, including any sentencing recommendation to be made by the prosecutor" and (2) "[p]resentation to the court of the victim's views regarding sentencing." 4 I They also direct him to "advocate the interests of victims at the time of sentencing." 42 On the other hand, the guidelines direct prosecutors to advise "victims of serious crime in a timely manner . . . [of] . . . the opportunity to address the court at the time of sentencing,"43 thereby recognizing the court's inherent discretion to hear the victim and the desirability of advising the victim of that discretion.

Where restitution is involved, both the Act and the guidelines take more explicit note of the victim's interest. The Act sets out a restitution procedure which approximates a civil action in which the victim is the real party in interest. 44 The "attorney for the Government" is treated as the representa-

38. The Act, 18 U.S.C. $\$ 3580(\mathrm{c})$ (1982), provides: "The court shall disclose to both the defendant and the attorney for the Government all portions of the presentence or other report pertaining to the matter described in subsection (a) of this section" which deals with information relevant to restitution. On procedures applicable to sentencing, see generally Williams v. New York, 337 U.S. 241 (1949); FED. R. C.Rim. P. 32(c); Fennell \& Hall, Due Process at Sentencing: An Empirical and Legal Analysis of the Disclosure of Presentence Reports in Federal Courts, 93 HARv. L. Rev. 1613 (1980); Note, Due Process and Legislative Standards in Sentencing, 101 U. PA. L. REv. 257 (1952).

According to a recent study by Professor Josephine Gittler, eighteen states now require some form of victim impact statement in the presentence report. Gittler, Expanding the Role of the Victim in a Criminal Action: An Overview of Issues and Problems, 11 Pepperdine L. Rev., 117,173 n. 175 (1984). Five states expressly permit the victim to be present and heard at sentencing under certain circumstances. Id. at 175. In the latter group are Alabama, which restricts the right to hearings on restitution, ALA. CODE \$ 15-18-7 (1982); California, which authorizes such appearance at sentencing of felony offenders but gives the court discretion to withdraw the right if the victim has testified at trial, CAL. Penal Code $\$ 1203(\mathrm{~h})$ (West Supp. 1984); Connecticut, which gives victims the right "to make or submit a statement" at sentencing of most felonies, Conn. Gen. STat. \$ 54-91 c(b) (1983); Florida, which authorizes statements by victims orally or in writing where offender has pleaded guilty or nolo contendre, Fla. Stat. ANN. $\$ 921.143$ (1) (West Supp. 1983); and Maine, Me. Rev. Stat. AnN. tit. 17 A, $\$ 1257(2)$ (West Supp. 1983).

39. FEd. R. CRIM. P. 32(c)(1),(2).

40. See 18 U.S.C. $\$ 1512$ note (1982).

41. Attorney General's Guidelines, supra note 15 , \& II(C)(5),(8).

42. Id. § III. Such advocacy should be made if it is "consistent with . . . the prosecutor's other responsibilities." Id.

43. Id. $\S \mathrm{II}(\mathrm{B})(8)$.

44. Yet the Act is not clear on whether the hearing on sentence and restitution need be any more formal than the sentencing process itself now is. What may still be contemplated is a "summary procedural pattern" involving some degree of notice and opportunity to be heard in a degree appropriate to the interests in issue. See Harland, Restitution Statutes and Cases: Some Substantive and 
tive of the victim and carries the burden of proving "the amount of the loss sustained by a victim as a result of the offense." 45 Under the guidelines, the prosecutor is directed to "advocate fully the rights of victims on the issue of restitution unless such advocacy would unduly prolong or complicate the sentencing proceeding." 46 Since the victim is not mentioned as a party and the prosecutor must advocate the victim's interests fully, it would seem that he is meant to be the victim's surrogate on restitution matters. Arguably, that surrogate role extends to the restitution issue in the context of charging, dismissals, and guilty pleas. This interpretation also draws support from the Act's provision for a victim impact statement which defines a relationship between judge and victim independent of the prosecutor. ${ }^{47}$ The victim is even told in the guidelines that he may bypass the prosecutor and communicate directly with the probation officer. ${ }^{48}$ Presumably, therefore, if the prosecutor-as-surrogate makes no effort to ascertain the victim's views regarding sentencing and restitution, or fails to communicate those views when they disagree, the sentencing judge may seek the victim's views directly-either through the probation officer or by calling the victim as a witness or inviting him to appear as a limited party or amicus curiae. ${ }^{49}$

Procedural Constraints, in Victims, Offenders, and Alternative Sanctions 151 (J. Hudson \& B. Galaway eds. 1980) (citing Morrissey v. Brewer, 408 U.S. 471 (1972)). For a discussion of the English experience with "compensation orders," see Vennard, Magistrates' Assessments of Compensation for Injury, [1979] CRIM. L. REV. 510.

45. 18 U.S.C. $\$ 3780$ (d) (1982).

46. AtTorney General's Guidelines, supra note 15 , § IV.

47. See FEd. R. CRIM. P. 32(c)(1), (2).

48. Id. \$ III ("The victim should be advised as to how to communicate directly with the Probation Officer if he or she so desires"). The Act, after referring to issues on which the defendant must bear the burden of proof, seems to give the court a broad license to designate, "as justice requires," the party who is to carry the burden of proof in "such other matters as the court deems appropriate." 18 U.S.C. $\$ 3780$ (d) (1982). But the context suggests that it is one or the other of the parties already named who are to be designated, not the victim who is nowhere referred to as a party. See id.

49. The Committee Report on the Act says: "The Committee regards the victim impact statement as a first step to ensure that the victim's side is heard and considered by adjudicative offcials. . . . The Committee also agrees with the statement . . . that the victim impact statement 'allows the victim of the offense some privilege of allocution at the sanctioning phase of the proceedings.' " S. REP. 532, 87th Cong., 2d Sess. 13, reprinted in 1982 U.S. Code Cong. \& AD. News 2515, 2519.

In my article, Defining the Role of the Victim in Criminal Prosecution, supra note 3, at 553-54, I suggested that Trbovich v. Uniced Mine Workers, 404 U.S. 528 (1972), supports the view that "there is no necessary conflict between retaining the prosecutor's exclusive authority to initiate a suit and providing a role for the victim in subsequent stages of the suit":

[The Court] saw no bar to participation by union members (the victims) in the Secretary's suit so long as that participation did not interfere with the screening and centralizing function of the Secretary. Because the union wished only to present evidence and argument in support of the Secretary's complaint, it could intervene. But it would not be permitted to add to the complaint other grounds for setting aside the election; such additions would circumvent the screening function assigned by statute to the Secretary.

Id. A significant gloss on Trbovich appears in Brennan v. United Steelworkers of Am., 554 F.2d 586 (3d Cir. 1977), cert. denied, 435 U.S. 977 (1978). In dicta, the court distinguished the independent role of the intervening union member from that of the Secretary of Labor:

The Department of Labor performs a quasi-judicial, rather than a purely adversarial role in Title IV cases. Its duty is to the public, its own policies, the union interest, and the individual. In deciding whether to institute suit, what to complain of, and what to settle for, the Secretary must constantly weigh competing interests and duties. . . But since Trbovich, the union interest is 
The distinction in the guidelines between the prosecutor's obligation to engage in victim advocacy at sentencing (and restitution) and to merely "consult" victims at earlier stages of the process appears to have been deliberate. Consultations and explanations at the earlier "prosecutorial" stages are apparently meant to be part of an internal administrative process. Sentencing and restitution, on the other hand, are judicial decisions. The victim's views are to be taken into account by judges exercising their discretion after conviction just as those views are to be taken into account earlier by prosecutors in making their decisions.

The emphasis up to this point has been on communication between victim and prosecutor. Defendants, of course, will want to know what victims are saying to the prosecutor-on the reasonable assumption that their offenses may be distorted and their dangerousness exaggerated by victims, and that judges will rely heavily on the prosecutor's recommendation. This issue replicates the classic question whether the defendant may have access to the presentence report used by the sentencing judge. ${ }^{50}$ The problem could be resolved easily if the prosecutor were to notify the defendant of the victim's views at the relevant "prosecutorial" stages. If this early disclosure risks making the prosecutor's consultation too much into a hearing of its own or providing too much information before trial or guilty plea, disclosure may be deferred until the victim's views are transmitted to the judge-at which point the defendant may rebut both the victim and the prosecutor.

\section{The "Preclusion" Provisions and Judicial Review}

There is no doubt that the prosecutor is obligated under the Act to consult the victim. But there is a good deal of doubt as to what the court can do if the prosecutor does not carry out his obligations-if, for example, he does not consult the victim at all; or does not consult in good faith; or does not give the explanations called for by the guidelines; or does not communicate the victim's views to the court in appropriate cases. The doubt arises from provisions in the Act and the guidelines which purport to restrict the role of the

defined by two parties with adverse viewpoints-even if their interest in the union remains a common denominator. . . The intervenor's role created by Trbovich is thus that of an adversary to the union in developing the facts and the legal issues.

Id. at 599. It may be suggested that the court has no authority, in the absence of statute, to treat the victim as a limited party, a species of intervenor. Cf. FED. R. CIV. P. 24(a). But there would be no bar to the victim's acting as amicus curiae. Amicus curiae status is currently left to a court's discretion. And the standards for conferring it are not restrictive. The ability to provide the court with timely and useful information is sufficient, as is a need to protect one's own interests because of inadequate representation by the parties to the case. Normally an amicus curiae does not have a right to appeal a final judgment or a right to call witnesses or a right to introduce evidence. But there have been exceptions. For example, amici have been allowed, under special circumstances, to commence injunction proceedings and proceedings for contempt; to file appeals; to call witnesses and ask questions. It should be noted, however, that the most extensive use of the amicus role has occurred in cases in which the federal government sought it or was asked by the court to assume it. Krislov, The Amicus Curiae Brief: From Friendship to Advocacy, 72 YaLE L.J. 694, 720 (1963); M. Hepworth, The Victim as Amicus Curiae at Sentencing Hearings, 16-17 (unpublished student paper, Yale Law School, 1983).

50. See supra note 38 . 
courts and which suggest that the victim may be limited to his administrative remedy of complaining to the United States Attorney and/or the Attorney General.

Section 6(b) of the Act provides: "Nothing in this title shall be construed as creating a cause of action against the United States." 51 Despite the apparent breadth of this provision, it comes against a background of cases in which the courts have treated official action as presumptively subject to judicial review, either under the Administrative Procedure Act or under the courts' inherent power. ${ }^{52}$ To enforce that presumption, the courts have given remarkably narrow constructions to statutes which purport to limit review ${ }^{53}$ by stating that the action of the Attorney General "shall be final and unreviewable" or that it "shall not be reviewable in any court." 54 In the world of "preclusion" statutes, section $6(\mathrm{~b})^{55}$ contrasts markedly with such formulae. Some

51. 18 U.S.C. $\$ 1512$ note (1982).

52. K. Davis, Administrative Law Text ch. 28 (3d ed. 1972 \& Supp. 1982).

53. See id.; B. Schwartz, Administrative Law 438-54 (1976); $c f$. Stewart \& Sunstein, Public Programs and Private Rights, 95 Harv. L. Rev. 1193, 1267-89 (1982). In Adams v. Richardson, 480 F.2d 1159 (D.C. Cir. 1973), the court upheld a suit to compel enforcement by the Department of Health, Education and Welfare of the requirements of the Civil Rights Act with regard to federally assisted programs dealing with school desegregation. The court rejected the argument that such enforcement may not be reviewable under the Administrative Procedure Act because it is committed to agency discretion, saying:

$[T]$ he agency discretion exception to the general rule that agency action is reviewable under the ... Act, is a narrow one. . . Appellants rely almost entirely on cases in which courts have declined to disturb the exercise of prosecutorial discretion by the Attorney General or by United States Attorneys. . . . Those cases do not support a claim to absolute discretion and are, in any event, distinguishable from the case at bar. Title VI not only requires the agency to enforce the Act, but also sets forth specific enforcement procedures.

Id. at 1161-62. The court concluded:

In this suit against the agency, in contrast to actions brought against individual school systems, our purpose, and the purpose of the District Court order as we understand it, is not to resolve particular questions of compliance or noncompliance. It is, rather, to assure that the agency properly construes its statutory obligations, and that the policies it adopts and implements are consistent with those duties and not a negation of them.

Id. at 1163-64 (footnotes omitted).

54. In Johnson v. Robison, 415 U.S. 361 (1974), the Court considered 38 U.S.C. \$ 211 (a) (1982), which prohibits judicial review of "the decisions of the Administrator on any question of law or fact under laws administered by the Veterans' Administration providing benefits for veterans . . . shall be final and conclusive and no . . . court of the United States shall have power or jurisdiction to review any such decision." The Court noted that

Appellee's constitutional challenge is not to any [particular] . . decision of the Administrator, but rather to a decision of Congress to create a statutory class entitled to benefits that does not include $1-0$ conscientious objectors who performed alternative civilian service.

Id. at 367. Therefore the Court found that

neither the text nor the scant legislative history of $\S 211$ (a) provides the clear and convincing evidence of congressional intent required by this Court before a statute will be construed to restrict access to judicial review. See Abbott Laboratories v. Gardner, 387 U.S. 136, 141 (1967).

Id. at 373-74. An illustration of extraordinarily specific statutory language on the unavailability of judicial review is to be found in 42 U.S.C. $\$ 7617$ (e) (1982), which provides: "Nothing in this section shall be construed . . . (3) to authorize or require any judicial review of any such standard or regulation, or any stay or injunction of the proposal, promulgation, or effectiveness of such standard or regulation on the basis of failure to comply with this section." See also Dunlop v. Bachowski, 421 U.S. 560 (1975), in which the Court confined the scope of review to the requirement that the Secretary of Labor must provide a statement of reasons supporting his determination as to a union election. In that case, that Court would not consider stepping in unless the Secretary's determination was "so irrational as to constitute the decision arbitrary and capricious." Id. at 575.

55. Atrorney General's Guidelines, supta note 15 , § Vil. 
indication of what Congress might have said on this matter, but did not, is the language incorporated by the Attorney General in section VII of the guidelines. That section, which tries to bar access to the courts entirely, reads:

These guidelines provide only internal Department of Justice guidance. They are not intended to, do not, and may not be relied upon to create any rights, substantive or procedural, enforceable at law by any person in any matter civil or criminal. Nor are any limitations hereby placed on otherwise lawful litigative prerogatives of the Department of Justice. Rather, these guidelines are intended to ensure that responsible officials, in the exercise of their discretion, treat victims and witnesses fairly and with understanding. ${ }^{56}$

When the limited language of section $6(\mathrm{~b})$ is read against the background of the broad "preclusion" language which Congress obviously knew how to use but did not, it seems reasonable to read section 6(b) as aimed not at total nonreviewability but at the risk of liability in damages arising from section 6(a)'s provisions for benefits, protection, and services to victims. ${ }^{57}$ Since section 6(a) might become the basis for damage actions by victims and witnesses when benefits are not provided or protections are not successful, Congress wrote a preclusion provision in section 6(b) with language denying a new "cause of action against the United States," in order to make clear that Congress had not implicitly waived sovereign immunity from civil liability.

The contrast between the two "preclusion" provisions-the limited one in the statute and the broader one in the guidelines-supports the inference that each one is directed at different objectives. The Attorney General's preclusion provision would treat the guidelines as matters to be initiated or not, applied or not, as he and his subordinates choose in the exercise of unreviewable discretion. There is, of course, precedent for such a position when the executive branch volunteers guidance to the public as to its enforcement policy. ${ }^{58}$ But these guidelines present a distinctive problem. They were not issued voluntarily by the Attorney General in the exercise of his executive discretion. He was directed by Congress to issue them in order to achieve specified purposes, based on a series of congressional findings about the role of the victim. ${ }^{59}$ Under such circumstances, his effort to take the guidelines

56. Id.

57. See supra note 17. S. REP. No. 532, 97th Cong., 2d Sess. 39, reprinted in 1982 U.S. ConG. \& AD. NEws 2515, 2545, also refers to state statutes providing for a "bill of rights" for victims and witnesses which include many provisions comparable to those in the federal statute. The Committee notes that "in most instances, the statutes do not assign responsibilities for enforcing the rights, do not provide sanctions for failing to implement them, and do not create a cause of action by private citizens to have the rights enforced. Thus, the 'rights' are more properly called 'guidelines' as they are termed in [the federal act]." However, none of the quoted provisions refers to consultation with victims at critical stages. See also infra note 67.

58. See, e.g., United States v. Caceres, 440 U.S. 741, 755-56 (1979).

59. See supra note 10 and accompanying text. S. Rep. No. 532, 97th Cong., 2d Sess. 39, reprinted in 1982 U.S. Code Cong. \& Ad. News 2515, 2545 also says: "[The Act] requires the Attorney General to develop guidelines addressing nine specified objectives. . . . While the Committee does not intend to limit the Attorney General to the nine objectives enumerated, it does require that the Attorney General address at least those nine, each of which has been successfully dealt with on the local level." 
entirely out of the realm of judicial enforcement seems to go too far. The structure of section 6 -including the limited preclusion language of subsection 6(a)-points toward some role for the victim and the courts, albeit a narrow one, in assuring that the congressional purpose is carried out by the Attorney General and his subordinates.

Distinctions may well be drawn for review purposes, however, between obligations arising from the Act (and the guidelines fairly contemplated by the Act) - as to which some degree of review attaches-and the additional obligations assumed by the Attorney General in order to implement the recommendations of the President's Task Force on Victims. For example, the Act specifies only four stages as occasions for consultation with victims; the guidelines specify five additional stages. If some or all of the latter obligations were assumed by the Attorney General pursuant to his "executive" power (rather than pursuant to congressional direction), they may indeed be "internal" guidelines which are immune from judicial scrutiny except in the most extraordinary circumstances.

\section{Scope of Judicial Review}

The issue regarding judicial review under the Act is not so much one of its availability as of its scope. A different scope of review may be required, for example, for the failure of the prosecutor to consult the victim at all at one of the four statutory stages and his failure to accept and advocate the victim's views after such consultation. The former may be compelled by the court but the latter may not be. Similarly, the court may compel the prosecutor to transmit the victim's views when it is the court which must exercise discretion and wishes to take those views into account - whether on pretrial release, sentencing, dismissal, or the guilty plea. The distinction to be made is the conventional one between, on the one hand, requiring officials to follow prescribed procedures and not intruding on their judgment in particular cases, and, on the other hand, limiting their intrusions only to cases where prosecutorial behavior "is clearly contrary to manifest public interest." 60 The five consultative stages prescribed by the guidelines present a more difficult problem. Since some of these are "internal" and "discretionary," they may not be subject to judicial review at all or a judicial remedy may be available only if the prosecutor is acting in a manifestly arbitrary manner.

If we assume that some judicial remedy may be available to the victim some of the time, the effectiveness of that remedy may turn on whether the victim must be told of the prosecutor's decision or recommendation before it is made or acted on by the court. For example, if the prosecutor proposes to dismiss or reduce a charge, is it necessary only that he consult the victim before making the motion, deferring the explanation required by the guidelines until after the judge has ruled on the motion? Or must the prosecutor

60. United States v. Cowan, 524 F.2d 504, 513 (5th Cir. 1975), cert. denied, 425 U.S. 971 (1976). See also United States v. Ammidown, 497 F.2d 615 (D.C. Cir. 1973). 
consult the victim, explain the basis for any disagreement, and then move to dismiss, with notice to the victim so that he may petition the court to present his views on the matter? The same sort of question can be raised for each of the decisions for which victim's views are to be sought and prosecutor's explanations given under the guidelines. Is the victim to have an opportunity to challenge or augment the prosecutor's presentation in advance of a decision by the court? The Senate report on the Act gives a clear answer to when the victim must be consulted on these questions. It says that "the non-binding consultation should precede recommendations on pretrial release, pretrial diversion, dismissal and plea negotiations."'61 An Indiana statute goes somewhat farther, in a manner which is consonant with the federal act's objectives. It provides that a prosecutor who recommends to the court that a charge should be dismissed, or that a defendant who pleads guilty should get less than the maximum penalty, must:

(1) Inform the victim that he has entered into discussions with defense counsel or the court concerning a recommendation;

(2) Inform the victim of the contents of the recommendation before it is filed; and

(3) Notify the victim so that he might be present when the court considers the recommendation. ${ }^{62}$

A court should have no difficulty in authorizing the victim, his counsel, or even his witnesses to participate in limited fashion in the informal judicial hearings already provided on dismissals, guilty pleas, and pretrial release. It would not follow, however, that a disappointed victim could routinely appeal from the decisions of the court on such matters. The role of the appellate court would appear to be limited to compelling the prosecutor or trial judge to "consult" the victim, as noted earlier, and to assess whether there has been a manifest abuse of discretion in a particular case.

\section{IV}

\section{Sources of Resistance}

Despite remarkable support from Congress, the President, the Attorney General, and the broadly based victims' movement, the Act's effort to define a role for the victim-whether through "consultation" or through awards of restitution-can be expected to meet a great deal of resistance from the principal actors in the criminal proceeding-the prosecutor, the defendant, and the judge. To many prosecutors and trial judges, the Act requires scarce personnel and resources to be given over to procedures which will have no discernible impact because the Act formalizes a relationship with the victim which already exists or which prosecutors and judges have decided for good reason should not exist. The transformation of restitution from an informal adjunct of sentencing to a virtual civil trial is offered as a telling illustration of

61. S. Rep No. 532, 97th Cong., 2d Sess. 40, reprinted in 1982 U.S. Code Conc. \& Ad. News 2515, 2546 (emphasis added).

62. Ind. Code ANN. \& 35-5-6-1.5(a) (Burns 1979). Section 3(b) provides that "A court may consider a recommendation on a felony charge only if the prosecutor has complied with this section." 
new burdens being imposed on an already overburdened judicial system. ${ }^{63}$ Even if a more limited role for the victim can be defined, it will make the criminal process longer, more costly, and more retributive. Moreover, the victim's interest in restitution may result in more charges for offenses which will facilitate financial recovery, at the expense of prosecution for.crimes involving little or no financial return to the victim-such as violent crimes by indigent offenders or victimless crimes.

The "burden" and "cost" arguments are closely related to the concern about retribution and belie the assertion that hearing the victim's views will make no difference. The concern seems rather to be that a process of consultation with the victim will make entirely too much difference-that it will lead to more and heavier charges, less plea bargaining, and heavier sentences, and that the public interest will suffer as a result. It is feared that victim pressure will inhibit the individualization required in the interest of rehabilitation and compassion, that criminal law will not be mitigated in the way legislators expect it to be when they enact harsh penalties, that more cases will be contested by defendants because they fear the increased burden of full restitution as well as heavier charges and sentences, and that courts and prisons will be overwhelmed by the increased volume of cases and prisoners.

It is not possible to generalize now on the degree to which victim consultation will burden the system or move prosecutors or judges in a more or less benign direction. It may be the victim who wishes to drop or reduce charges and the prosecutor who does not-as in the case of family disputes and crimes by friends and employees. On the other hand, the victim may be concerned with recovering his stolen property or securing restitution while the prosecutor wishes to prosecute so that he may set an example to others. To the victim, a sufficient deterrent purpose may have been served, in the only case which concerns him, by complaining to the police. He may see no need to drive the case on to judgment so that others will be deterred. Or he may have complained while angry but has now cooled off and no longer wants to be troubled by going to court. In such cases, it may be the prosecutor who is the source of maximum charges and the advocate of maximum sentences.

Obviously, the roles in each of these instances may be reversed. The victim's views may be more or less benign than the prosecutor's, depending on the context of the particular case. Only in limited categories of cases and situations are victims' views likely to be unidimensional. If certain classes of victims are organized, for example, a particular viewpoint may be pressede.g., by feminists against charge reduction in rape or domestic abuse cases, or by public interest groups pressing for enforcement of regulatory offenses.

A study conducted in Dade County, Florida, supports the view that it is

63. See the emphasis placed on the burdens imposed by the restitution provisions of the Act in the decision holding these provisions unconstitutional as violating the Seventh Amendment's requirement of jury trial in civil cases. United States v. Welden, 568 F. Supp. 516 (N.D. Ala. 1983). But of. cases holding that no jury trial is required: United States v. Brown, 744 F.2d 905 (2d Cir. 1984); United States v. Florence, 741 F.2d 1066 (8th Cir. 1984). 
risky to rely on stereotypes in predicting the consequences of victim participation. The study tested the effects of such participation in "pretrial settlement hearings" leading to guilty pleas. ${ }^{64}$ A random selection was made of 1074 cases, of which 378 were assigned to a test group in which judge, victim, and defendant were to participate. The remainder were assigned to control groups which followed the usual procedure. The victim in the experimental group was notified of each hearing and was invited to present his views. Court hearings were observed, participants were interviewed, and the results were analyzed. The victims who participated in the hearings were more pleased with the process and the results than were a comparable group who did not participate. Moreover, the victims proved to be less retributively inclined and less disruptive than prosecutors, judges, and defense counsel feared they might be. Even more surprisingly, victim participation seems to have added to the efficiency of the proceedings. There was an overall reduction in the length of time it took to process the case from formal charge to closing and a greater proportion of the test cases were closed on or before the scheduled trial date-apparently because the victim's presence facilitated communication among interested parties and crystallized views earlier as a result. ${ }^{65}$ Other studies have reached similar conclusions-among them that early communication between victim and prosecutor results in less reliance on police reports, which are often inadequate, and in a more informed exercise of prosecutorial discretion. 66

The risk of added vindictiveness from victim consultation has probably been overstated. First, in a large number of regulatory offenses and "victimless" crimes, such as tax evasion and narcotics trafficking, "the United States or the public generally are the victims." 67 The consultation, restitution, and victim impact provisions of the Act are inapplicable in such cases; there is no victim to be consulted, no new pressure to be anticipated. Even where a public agency is vested with primary responsibility for protecting a segment of the public interest and serves as a proxy victim in relation to the prosecutor, it is not likely to be any more vindictive than the prosecutor is.

Finally, as already suggested, victims are too varied to warrant generalizations about how retributive they will be. In many conventional crimes and frauds, the criminal charge is little more than a point of entry for troubled people seeking solutions to a remarkable range of "civil" problems. For such victims, the claims to criminal justice may easily be moderated by either mon-

64. Law Enforcement Assistance Admin., U.S. Dep't of Justice, Pretrial Settlement Conference: An Evaluation 1-7 (Heinz \& Kerstetter 1979). S. Rep. No. 532, 97th Cong., 2d Sess. 41, reprinted in 1982 U.S. Code Cong. \& AD. NEws 2515, 2547, comments on the basis of materials presented to the Committee, that "the effect of eliciting victim views on such discretionary decisions as a negotiated plea is not to undermine prosecutorial discretion, or to unduly burden the workload of assistant prosecutors, or to produce harsher punishments for offenders."

65. Law Enforcement Assistance Admin., supra note 64, at 126, 130, 131.

66. See Knudten, Meade, Knudten \& Doerner, The Victim in the Administration of Criminal Justice: Problems and Perceptions, in CRiminal Justice and the Victim 1 15, $118-21$ (W. McDonald ed. 1976); R. Davis, supra note 6, passim.

67. Attorney General's Guidelines, supra note 15, § I(D). 
etary recoveries in all manner of cases or mediated solutions for crimes among friends and neighbors. Giving victims a stake in the criminal process may thus be a way to reduce retributive impulses and at the same time channel the parties to remedies that may be an alternative to imprisonment. Victim participation may then become a device for decriminalization, particularly when augmented by an imaginative use of restitution.

An entirely different set of problems is presented by crimes of violence unmitigated by prior relationship and by crimes involving serious invasions of property and corruption. These crimes are too little enforced, often because the victim is unwilling to cooperate in a prosecution that no longer seems to have much relation to him. If the credibility of the criminal sanction is to be maintained, the victims of such crimes must be persuaded to cooperate, even if they are moved to do so by vindictive feelings. And such cooperation is a principal objective of the Act. ${ }^{68}$

Perhaps the most fundamental objection to a role for the victim is that it threatens a hard-won and coveted system of public prosecution. The very purpose of a body of criminal law and of a public prosecutor, it is said, is to channel the victim's feelings into a public cause of action which takes into consideration not only the victim's views and injuries but those of the larger society.

It is, of course, true that the movement from private to public prosecution represents an advanced stage in the evolution of criminal justice. But public prosecution remains inextricably linked to the earlier stage in theory and in practice. It is the victim's injury and outrage which is, after all, "channeled" into the public prosecution. In simple societies, this link between victim and public prosecutor is clear. The public official is a surrogate whose function is to provide assurance to the victim, his family, and his friends that they need take no punitive action and that the state will do what is necessary to bring the offender to justice. As societies become more complex-as more criminal laws are enacted for people who do not know one another and who are no longer organized to gather for vengeance and blood feud-the surrogate function becomes less visible and is almost forgotten. The prosecutor becomes another regulatory agency, administering a program of public control of criminal conduct in which policies of deterrence, rehabilitation, and retribution are to be weighed in the balance. He becomes increasingly susceptible to the exigencies of his situation-to the pressures of defendants, case loads, too many criminal laws, and unduly harsh sentences. As such, the prosecutor becomes less and less a representative of the victim. In short, his original "channeling" function is displaced by a broader and more public function. A major tenet of the victims' movement and the Act is the belief that the victim has been too much removed from the prosecution of the crime against him, that such removal underlies the common failure of victims to

68. See 18 U.S.C. § 1512 note (1982). 
report crime and to cooperate in its prosecution, and that the prosecutor must somehow be recalled to his original function.

Another form of the argument against a role for the victim is that there is something illegitimate about the "vindictive" views he is likely to proffer. Putting aside the questions whether "vindictive" is the correct word to describe the victim's sense of what justice requires or whether most victims are "vindictive," the claim of illegitimacy is plainly wrong. In their origins, criminal sanctions were based upon theories of retribution and deterrence. The office of public prosecutor was not established to abandon those theories or to usher in any particular penal philosophy. It was meant to make law enforcement more efficient and more credible by enhancing state authority and by persuading the larger community that there was no need to resort to self-help. It is primarily for the legislature to decide which of these philosophies should be reflected in the definition of crimes, the sanctions prescribed, and the directions given to law enforcement officials as to whom they should consult in making their decisions. The distinctive contribution of the Act is that it now requires the victim's views to be weighed in the balance. ${ }^{69}$

\section{V}

\section{Conclusion}

The new Act does not confer "standing" on the victim to initiate his own prosecutions and it probably does not authorize him to participate routinely as a party in any of the critical stages of the criminal justice system. Instead, it defines how the prosecutor is to exercise his discretion against a background of well-established assumptions about prosecutorial and judicial prerogatives. Nevertheless, the Act does provide some clear directives. It distinguishes sharply between the victim's relation to the prosecutor and his relation to the judge. The victim of serious crime is to be consulted regularly by the prosecutor and occasionally by the judge; more may perhaps be required at sentencing and restitution. Even then, the victim ordinarily has "standing" only to present his views (and evidence) to the probation officer or, if matters are contested, to the prosecutor who is to represent his interests.

The approach of the Act is not to establish for the victim a parity of status with prosecutor or defendant. It does not treat him as an intervening party but as representing an "interest" which must be taken into account in the

69. In Gregg v. Georgia, 428 U.S. 153, 183 (1976), the Court commented, in the course of upholding Georgia's provision for capital punishment, that the

expression of society's moral outrage. . . . may be unappealing to many, but it is essential in an ordered society that asks its citizens to rely on legal processes rather than self-help to vindicate their wrongs. "The instinct for retribution is part of the nature of man, and channeling that instinct in the administration of criminal justice serves an important purpose in promoting the stability of a society governed by law. When people begin to believe that organized society is unwilling or unable to impose upon criminal offenders the punishment they deserve, then there are sown the seeds of anarchy-of self-help, vigilante justice, and lynch law." Furman v. Georgia, 408 U.S. at 308 (Stewart, J., concurring). "Retribution is no longer the dominant objective of the criminal law," Williams v. New York, 337 U.S. 241, 248 (1949), but neither is it a forbidden objective nor one inconsistent with our respect for the dignity of men. 
differential manners appropriate to each of several specified decisions. The principal method used by the Act is to require the prosecutor to "consult" the victim. This approach is a long way from requiring the prosecutor to accept the victim's views and an even longer distance from judicial acceptance of those views. Indeed, there is the risk that such consultation will be perceived by victims as so plainly "cosmetic" in nature that they will not be moved at all to increase their cooperation and confidence in law enforcement.

Yet matters are never quite so simple. If victims must be consulted, prosecutors are likely to feel the pull towards doing so in good faith-because of their fidelity to the requirements of law and their fear of adverse publicity. The same is true of disagreement with the victim's views. Prosecutors and judges will be pressed to be responsive to an interest now being separated from the amorphous "public" interest and urged on them more often as deserving special consideration. Even so, Congress and the victims' movement must not expect too much. In the end, the victim's views, even when he appears personally, will be only one element in a wide variety of interests which prosecutor and judge-each in his respective sphere-must take into account. The distinctive thing about the victim is that he (like the defendant) is strategically located and motivated to watch closely how the law is being applied in a particular case-and to call attention to inaccuracy, illegality, and inequality in the administration of criminal justice. This need is particularly obvious in the context of sentencing and plea bargains, in charge reduction and dismissals, where prosecutor and defendant may have reached agreements which then have the effect of denying to the court the clash over issues of fact and law of the traditional adversary processes.

The critical question is whether hearing the victim's views will not only make him feel better but will also make the criminal justice system work more effectively. By becoming more attentive to the victim's situation, will it encourage more crime reporting and more cooperation with law enforcement authorities? Will it facilitate the abandonment of charges which ought perhaps never to have entered the criminal justice system at all? Will it lead to diversion of essentially "civil" matters out of the criminal justice system? Will it assure that prosecutors are not too casual about plea bargaining and sentence bargaining in cases of serious crime?

The Act initiates a major experiment in criminal justice and it will be a long while before the results are in. It may turn out that consulting the victim will become too complex-that the courts will construe "consultation" as imposing too many opportunities for victims to appear personally (and with counsel and/or witnesses) at certain stages, and too many compensatory obligations on defendants. Or it may turn out that more participation by the victim will not produce the expected cooperation with law enforcement because there are other reasons for not cooperating-such as fear of retaliation or loss of wages while in court or dispiriting trial delays. It will then be open to Congress, court, and Attorney General to conclude that the experiment has failed or that modifications must be made. On the other hand, if the 
[Vol. 47: No. 4

experiment with "consultation" disarms its critics and proves its worth, we can perhaps move on to consider additional ways to encourage participation by victims in the administration of criminal justice. 